\title{
Steering plasmonic hot electrons to realize enhanced full-spectrum photocatalytic hydrogen evolution
}

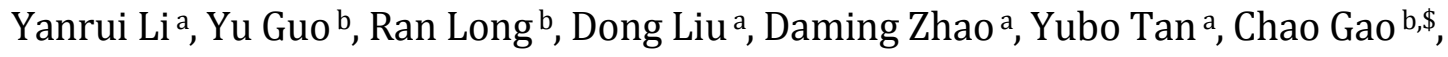

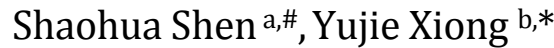 \\ a International Research Centre for Renewable Energy, State Key Laboratory of Multiphase Flow in Power Engineering, Xi'an Jiaotong University, Xi'an \\ 710049, Shaanxi, China \\ b Hefei National Laboratory for Physical Sciences at the Microscale, iChEM (Collaborative Innovation Center of Chemistry for Energy Materials), School of \\ Chemistry and Materials Science, University of Science and Technology of China, Hefei 230026, Anhui, China
}

\section{A R T I C L E I N F}

\section{Article history:}

Received 26 September 2017

Accepted 21 October 2017

Published 5 March 2018

\section{Keywords:}

Plasmonics

Surface heterojunction

Schottky junction

Photocatalytic hydrogen production

Full spectrum

\begin{abstract}
A B S T R A C T
Integration of surface plasmons into photocatalysis is an intriguing approach to extend the light absorption range over the full solar spectrum. However, the low migration rates and uncertain diffusion directions of plasmonic hot electrons make their photocatalytic efficiency fail to meet expectations. It remains a challenging task to steer the migration of hot electrons and take full advantage of the plasmonic effect to achieve the desired high photocatalytic efficiency. Herein, we have developed an efficient strategy to steer the migration of plasmonic hot electrons through a well-designed hybrid structure that synergizes a "surface heterojunction" with a Schottky junction. The hybrid structure was synthesized by modifying titanium dioxide $\left(\mathrm{TiO}_{2}\right)$ nanosheets (NSs) with gold $(\mathrm{Au})$ nanoparticles (NPs) as a plasmonic metal and platinum (Pt) NPs as a co-catalyst. The "surface heterojunction" formed between two different crystal facets in the $\mathrm{TiO}_{2} \mathrm{NSs}$ can induce the injection of plasmonic hot electrons from $\mathrm{Au}$ NPs excited by visible light to $\mathrm{TiO}_{2}$. Meanwhile, the Schottky junction formed between the Pt NPs and $\mathrm{TiO}_{2}$ NSs can force the migration of electrons from $\mathrm{TiO}_{2}$ to Pt NPs instead of flowing to Au NPs, attaining the efficient unidirectional transfer of carriers in the $\mathrm{Au}-\mathrm{TiO}_{2}$ system. Plasmonic photocatalysts with this design achieved dramatically enhanced activity in full-spectrum photocatalytic hydrogen production. This work opens a new window to rationally design hybrid structures for full-spectrum photocatalysis.
\end{abstract}

(C) 2018, Dalian Institute of Chemical Physics, Chinese Academy of Sciences. Published by Elsevier B.V. All rights reserved.

\section{Introduction}

Photocatalytic hydrogen evolution is a promising approach to address current energy and environmental demands. Ideal

\footnotetext{
* Corresponding author. Tel/Fax: + 86-551-63606657; E-mail: yjxiong@ustc.edu.cn

\# Corresponding author. Tel/Fax: +86-29-82668296; E-mail: shshen_xjtu@mail.xjtu.edu.cn

\$Corresponding author. Tel/Fax: +86-551-63600651; E-mail: gaoc@ustc.edu.cn

This work was supported in part by the National Key Research \& Development Program of China (2017YFA0207301), the National Basic research and Development Program of China (973 Program, 2014CB848900), the National Natural Science Foundation of China (21471141, U1532135), CAS Key Research Program of Frontier Sciences (QYZDB-SSW-SLH018), CAS Interdisciplinary Innovation Team, Innovative Program of Development Foundation of Hefei Center for Physical Science and Technology (2016FXCX003), Recruitment Program of Global Experts, CAS Hundred Talent Program, Anhui Provincial Natural Science Foundation (1708085QB26), China Postdoctoral Science Foundation (BH2060000034), and Fundamental Research Funds for the Central Universities (WK2060190064).

DOI: 10.1016/S1872-2067(17)62938-3 | http://www.sciencedirect.com/science/journal/18722067 | Chin. J. Catal., Vol. 39, No. 3, March 2018
} 
solar-to-fuel photocatalysts should harvest the broad spectrum of solar light to maximize the formation of photoinduced electron-hole pairs. It remains an important challenge to develop photocatalysts that can harvest the full solar spectrum to achieve efficient solar energy conversion. Titanium dioxide $\left(\mathrm{TiO}_{2}\right)$ has attracted much attention because of its great potential in photocatalysis and solar cells [1-5]. However, because $\mathrm{TiO}_{2}$ has a wide bandgap $(\sim 3.2 \mathrm{eV})$, it can only absorb ultraviolet (UV) light, which accounts for just ca. $5 \%$ of the solar spectrum [6]. Given this situation, great effort has been made to extend the light absorption of $\mathrm{TiO}_{2}$ to the visible spectral region, typically by combining it with narrow-bandgap semiconductors [7-9] or dye molecules [10,11]. In particular, plasmon-mediated photocatalysis has attracted considerable attention from researchers interested in semiconductor photocatalyst systems [12-16]. Recently, the development of plasmonic gold $(\mathrm{Au})[17,18]$ and silver $(\mathrm{Ag})[19,20]$ has offered $\mathrm{TiO}_{2}$ a new opportunity to achieve visible-light photoactivity via the plasmonic effect.

Taking plasmonic $\mathrm{Au}$ as a model system, it demonstrates plasmon-enhanced photoactivity when directly contacting a semiconductor. When irradiated by visible light, the electrons in the $d$-band of Au nanoparticles (NPs) can be excited to empty bands above the Fermi level $\left(E_{\mathrm{F}}\right)$ to form "hot electrons", leaving equilibrated $d$-band "hot holes" below $E_{\mathrm{F}}$ [21]. These hot electrons can inject into the conduction band (CB) of n-type semiconductors and initiate reduction reactions [22]. Recently, several $\mathrm{Au}-\mathrm{TiO}_{2}$ hybrid systems that display plasmon-enhanced photoactivity in the visible-light region because of the plasmonic absorption of Au NPs have been reported [23-25]. However, the plasmon-enhanced photoactivity of these $\mathrm{Au}-\mathrm{TiO}_{2}$ hybrid systems has been primarily restricted to the visible region. In these cases, $\mathrm{TiO}_{2}$ cannot be excited by visible light, and only plays roles in separating and transferring the injected electrons from Au NPs. When irradiated under the full solar light spectrum, $\mathrm{TiO}_{2}$ and plasmonic Au NPs are simultaneously excited. In this case, the injection of plasmonic hot electrons from $\mathrm{Au}$ NPs to $\mathrm{TiO}_{2}$ is counteracted by the opposite flow of photogenerated electrons from $\mathrm{TiO}_{2}$ to $\mathrm{Au}$ NPs determined by the Schottky junction, weakening the plasmonic effect. To make full use of plasmonic hot electrons and achieve full-spectrum photocatalysis, it is necessary to steer the migration of plasmonic hot electrons from Au NPs and photogenerated electrons from $\mathrm{TiO}_{2}$ in the desired directions.

Herein, we develop a hybrid structure to steer the migration of electrons in the desired direction, which enables the full use of plasmonic hot electrons to realize full-spectrum photocatalysis. In this design, a "surface heterojunction" is synergized with a Schottky junction. The "surface heterojunction" consists of a semiconductor with two or more different exposed crystal facets, in which electrons can be transferred from the facet with higher $E_{\mathrm{F}}$ to the facet with lower $E_{\mathrm{F}}$ by the internal electric field because of their different electronic states [26,27]. When plasmonic Au NPs are deposited onto the facet with higher $E_{\mathrm{F}}$, hot electrons can be efficiently steered towards the facet with lower $E_{\mathrm{F}}$. Meanwhile, a Schottky junction can be formed through the intimate contact between the noble metal NPs and n-type semiconductor when the work function of the noble metal is higher than that of the n-type semiconductor [22]. Driven by the Schottky junction, the photogenerated carriers on the semiconductor can be separated more efficiently, thereby enhancing the photocatalytic activity of the structure [28-31]. Platinum $(\mathrm{Pt})$ is a widely used co-catalyst that possesses a high work function to form the Schottky junction and thus can efficiently separate the photogenerated electrons from the semiconductor [32].

In this work, we use $\mathrm{TiO}_{2}$ nanosheets (NSs) covered with $\{001\}$ and $\{101\}$ facets as a model "surface heterojunction". Au NPs as the plasmonic metal are anchored on the $\{001\}$ surface of $\mathrm{TiO}_{2}$ by the intermediate ligand 3-mercaptopropionic acid (MPA). This structure can achieve facile injection of hot electrons because of the internal electric field of the "surface heterojunction" in the $\mathrm{TiO}_{2}$ NSs. To prevent the backflow of electrons from $\mathrm{TiO}_{2}$ NSs to Au NPs under full-spectrum irradiation, we integrate co-catalyst Pt NPs with the designed $\mathrm{Au}-\mathrm{TiO}_{2}\{001\}$ sample to form a Schottky junction. This Schottky junction can force the migration of electrons from $\mathrm{TiO}_{2}$ to Pt NPs instead of flowing back to Au NPs to realize the efficient unidirectional transfer of electrons in the $\mathrm{Au}-\mathrm{TiO}_{2}$ system. This hybrid structure is a highly efficient catalyst for full-spectrum photocatalytic hydrogen production. This work provides fresh insights into the rational design of photocatalyst structures that steer plasmonic hot electrons, representing a step towards full-spectrum photocatalysis.

\section{Experimental}

\subsection{Synthesis}

$\mathrm{TiO}_{2}$ NSs were synthesized by the solvothermal method as reported previously [33]. Typically, hydrofluoric acid (HF) aqueous solution $(4.5 \mathrm{~mL}, 40 \mathrm{wt} \%)$ was added to tetrabutyl titanate $(25 \mathrm{~mL})$ and stirred for $30 \mathrm{~min}$. Subsequently, the mixture was transferred into a $50-\mathrm{mL}$ Teflon-lined autoclave and kept at $180{ }^{\circ} \mathrm{C}$ for $24 \mathrm{~h}$. After the solvothermal reaction, the obtained white precipitate was collected, washed with deionized water and ethanol several times, and then calcined at $550{ }^{\circ} \mathrm{C}$ for $2 \mathrm{~h}$ in a furnace to remove surface fluoride ions.

In a standard process, sodium citrate dihydrate $(107.04 \mathrm{mg})$ and $\mathrm{HAuCl}_{4} \cdot 4 \mathrm{H}_{2} \mathrm{O}(4.79 \mathrm{~mL}, 0.1 \mathrm{~mol} / \mathrm{L})$ were mixed in deionized water $(93 \mathrm{~mL})$. The stirred mixture was heated at 80 ${ }^{\circ} \mathrm{C}$ for $2 \mathrm{~h}$ in a $250-\mathrm{mL}$ round-bottom flask. The as-synthesized Au NPs were dispersed in the solution by sonication and stored for further use. The concentration of Au NPs was measured by inductively coupled plasma mass spectrometry (ICP-MS).

The $\mathrm{Au}-\mathrm{TiO}_{2}\{001\}$ hybrid structure was obtained using MPA as an intermediate ligand [34]. In brief, $\mathrm{TiO}_{2} \mathrm{NSs}$ (20 mg) were added to a 50-mL quartz tube containing deionized water $(20 \mathrm{~mL})$, and then sonicated to form a uniform suspension. Then, MPA $(50 \mu \mathrm{L})$ was dispersed in the suspension by stirring for $6 \mathrm{~h}$. After the reaction, the sample was collected and washed with deionized water by centrifugation to remove the dissociated MPA. The obtained MPA-modified $\mathrm{TiO}_{2}$ NSs were dispersed in deionized water $(20 \mathrm{~mL})$ by sonication in a $50-\mathrm{mL}$ 
quartz tube. Subsequently, the as-synthesized Au NPs (2 mg) were mixed with the suspension by stirring for $6 \mathrm{~h}$. The product was isolated by centrifugation and washed with deionized water and ethanol several times. To remove MPA, the product was calcined at $200{ }^{\circ} \mathrm{C}$ for $1 \mathrm{~h}$ in an Ar atmosphere.

The $\mathrm{Au}-\mathrm{TiO}_{2}\{101\}$ hybrid structure was fabricated by directly photodepositing $\mathrm{Au}$ NPs on the $\{101\}$ facets of $\mathrm{TiO}_{2}$ NSs. In a typical synthesis, deionized water $(20 \mathrm{~mL})$ was added to a 50-mL quartz tube and purged with Ar for $30 \mathrm{~min}$ to remove air. Then, $\mathrm{TiO}_{2} \mathrm{NSs}(20 \mathrm{mg}), \mathrm{HAuCl}_{4} \cdot 4 \mathrm{H}_{2} \mathrm{O}(2 \mathrm{~mL}, 12.6$ $\mathrm{mmol} / \mathrm{L})$, and methanol ( $1 \mathrm{~mL}$ ) were added to the quartz tube, which was subsequently sonicated for $30 \mathrm{~min}$. The stirred mixture was irradiated by a $300-\mathrm{W}$ Xe lamp for $10 \mathrm{~min}$. After the reaction, the product was isolated by centrifugation, washed with deionized water and ethanol several times, and dried at $60^{\circ} \mathrm{C}$ under vacuum.

The $\mathrm{Au}-\mathrm{TiO}_{2}\{101\}-\mathrm{Pt}$ hybrid structure was fabricated by a chemical reduction method. In a typical synthesis, $\mathrm{H}_{2} \mathrm{PtCl}_{6} \cdot 6 \mathrm{H}_{2} \mathrm{O}$ $(0.77 \mathrm{~mL}, 2 \mathrm{mmol} / \mathrm{L})$ was added to deionized water $(15 \mathrm{~mL})$. As-synthesized $\mathrm{Au}-\mathrm{TiO}_{2}\{101\}$ (12 mg) was dispersed in the solution, which was then stirred for 30 min. Then, $\mathrm{NaBH}_{4}(1.5$ $\mathrm{mL}, 10 \mathrm{mmol} / \mathrm{L}$ ) solution was added to the suspension. After stirring for $10 \mathrm{~min}$, the product was isolated by centrifugation, washed with deionized water and ethanol several times, and then dried at $60^{\circ} \mathrm{C}$ under vacuum.

\subsection{Characterization}

The morphology of all samples was investigated by transmission electron microscopy (TEM; JEOL JEM-2100F, 200 $\mathrm{kV}$ ) and high-resolution transmission electron microscopy (HR-TEM; FEI, G2 F30, USA). Powder X-ray diffraction (XRD) patterns were recorded using a Philips X'Pert Pro Super X-ray diffractometer with $\mathrm{Cu}-K_{\alpha}$ radiation $(\lambda=1.5418 \AA)$. The concentrations of $\mathrm{Pt}$ and $\mathrm{Au}$ elements were measured with a Thermo Scientific PlasmaQuad 3 ICP-MS after dissolving the samples in a mixture of $\mathrm{HCl}$ and $\mathrm{HNO}_{3}$ with a volume ratio of 3:1. The ultraviolet-visible-near infrared (UV-vis-NIR) diffuse reflectance spectra of as-synthesized samples were recorded in the spectral region of 200-1000 nm with a Shimadzu SolidSpec-3700 spectrophotometer. Photoluminescence (PL) measurements were carried out on a Jobin Yvon Horiba Fluorolog-3-Tau spectrofluorometer.

\subsection{Photoelectrochemical measurements}

The photoelectrochemical measurements were carried out in a three-electrode quartz cell filled with $\mathrm{Na}_{2} \mathrm{SO}_{4}$ electrolyte ( $0.5 \mathrm{~mol} / \mathrm{L}$ ) under irradiation of a $300-\mathrm{W}$ Xe lamp (Solaredge 700, China). The $\mathrm{Na}_{2} \mathrm{SO}_{4}$ electrolyte was deoxygenated with $\mathrm{Ar}$ for $30 \mathrm{~min}$ prior to the measurements. $\mathrm{TiO}_{2} \mathrm{NSs}(2.0 \mathrm{mg})$ and $\mathrm{Au}-\mathrm{TiO}_{2}(2.4 \mathrm{mg})$ were dispersed in ethanol $(1 \mathrm{~mL})$ and then uniformly deposited onto a $2.5 \times 2.5 \mathrm{~cm}$ indium tin oxide (ITO)-coated glass substrate (SC-1B, China) to form a photoelectrode. Pt gauze and $\mathrm{Ag} / \mathrm{AgCl}$ were used as the counter and reference electrodes, respectively. The photoresponses of the prepared photoelectrodes (i.e., current $(I)$-time $(t)$ curves) were measured on a $\mathrm{CHI}$ 660D electrochemical station (Shanghai Chenhua, China) at a bias potential of $0.6 \mathrm{~V}$ (vs. $\mathrm{Ag} / \mathrm{AgCl}$ ) for $200 \mathrm{~s}$. Visible or full-spectrum light as an illumination source was realized in the presence or absence of a 400-nm long-wave-pass cutoff filter (i.e., $\lambda>400 \mathrm{~nm}$ ).

\subsection{Photocatalytic hydrogen production measurements}

To investigate the photocatalytic hydrogen production performance of the $\mathrm{TiO}_{2}$-based catalysts, methanol was used as sacrificial agent to scavenge the photogenerated holes. The photocatalysts were dispersed in a methanol aqueous solution (15 mL, 25 vol\% methanol) and deoxygenated with Ar. In the measurements for hot electron injection, $\mathrm{Au}-\mathrm{TiO}_{2}\{101\}$ and $\mathrm{Au}-\mathrm{TiO}_{2}\{001\}$ hybrid structures (12 mg) were used. To evaluate the photoactivity over the full light spectrum, the weights of $\mathrm{TiO}_{2} \mathrm{NSs}, \mathrm{TiO}_{2} \mathrm{NSs}-\mathrm{Pt}$, and $\mathrm{Au}-\mathrm{TiO}_{2}\{001\}-\mathrm{Pt}$ used were $10,10.3$, and $12.3 \mathrm{mg}$, respectively. The light irradiation experiments were typically performed for $4 \mathrm{~h}$ under a 300-W Xe lamp (Solaredge 700, China) in the presence or absence of a 400-nm long-wave-pass cutoff filter (i.e., $\lambda>400 \mathrm{~nm}$ ). The amount of hydrogen evolved was determined using gas chromatography (GC; 7890A, TCD, Ar carrier, Agilent). Three replicates were collected for each sample with a relative error of $<10 \%$.

\section{Results and discussion}

$\mathrm{TiO}_{2}$ is a typical UV-active wide-bandgap $(\sim 3.2 \mathrm{eV})$ n-type semiconductor [35-37]. The TEM image in Fig. 1(a) reveals that the $\mathrm{TiO}_{2} \mathrm{NSs}$ synthesized via a simple hydrothermal route [33] had an edge length of 25-35 $\mathrm{nm}$ and thickness of 6-7 nm. The as-synthesized $\mathrm{TiO}_{2} \mathrm{NSs}$ are enclosed by eight equivalent $\{101\}$ facets and two $\{001\}$ facets (Fig. 1(b)), and their crystal structure can be indexed to the anatase phase with lattice constants of $a=0.352 \mathrm{~nm}$ and $c=0.378 \mathrm{~nm}$ (JCPDS No.21-1272) [36] according to their powder XRD pattern (Fig. 1(c)). The HRTEM images of the $\mathrm{TiO}_{2}$ NSs show that their lattice spacings are about 0.23 and $0.19 \mathrm{~nm}$ (Fig. 1(d) and (e)), consistent with the (001) and (200) planes of anatase $\mathrm{TiO}_{2}$ [36], respectively. A "surface heterojunction" can form in $\mathrm{TiO}_{2}$ NSs covered with $\{001\}$ facets with higher $E_{\mathrm{F}}$ and $\{101\}$ facets with lower $E_{\mathrm{F}}$ $[27,36]$. When irradiated by UV light, the photogenerated electrons will migrate from the $\{001\}$ facets of anatase $\mathrm{TiO}_{2}$ to the $\{101\}$ facets, while the holes will transfer from the $\{101\}$ facets to $\{001\}$ ones, promoting the separation of photogenerated electrons and holes (Fig. 1(f)).

The second step of our design is to achieve the facet-dependent charge migration along with the injection of plasmonic hot electrons. Au NPs with an average size of $10 \mathrm{~nm}$ that exhibit a plasmonic band in the visible spectral range were selected as the plasmonic model in our research. We integrated the plasmonic $\mathrm{Au}$ NPs with $\mathrm{TiO}_{2}$ NSs in two ways: (1) by assembly on the $\{001\}$ facet of $\mathrm{TiO}_{2} \mathrm{NSs}$ through an intermediate ligand (denoted as $\mathrm{Au}-\mathrm{TiO}_{2}\{001\}$ ); and (2) anchoring on the $\{101\}$ facet of $\mathrm{TiO}_{2}$ NSs by photoreduction (denoted as $\mathrm{Au}-\mathrm{TiO}_{2}\{101\}$ ). To synthesize $\mathrm{Au}-\mathrm{TiO}_{2}\{001\}$ (Fig. 2(a)), MPA 

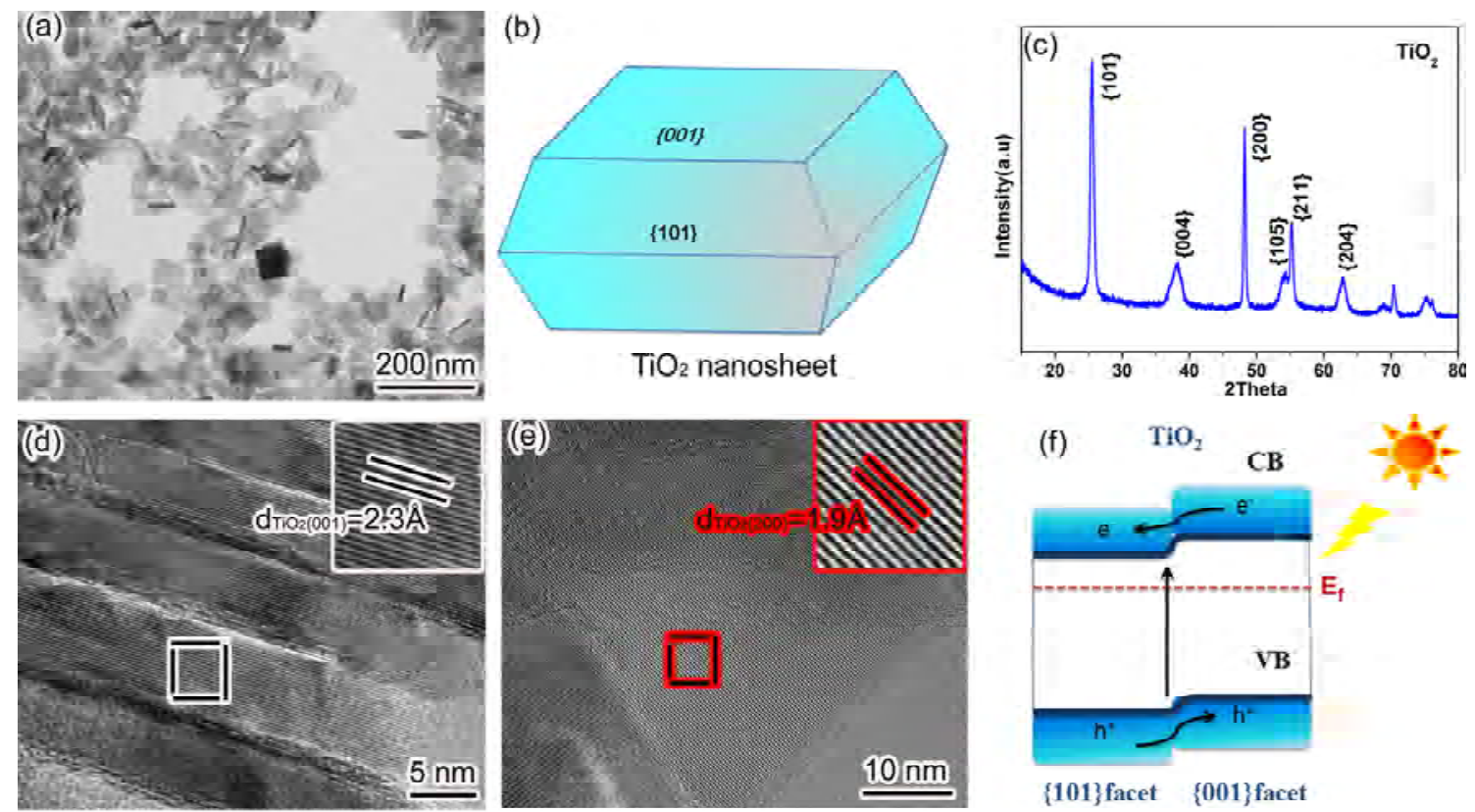

Fig. 1. (a) TEM image of $\mathrm{TiO}_{2}$ nanosheets. (b) Schematic illustration of a $\mathrm{TiO}_{2}$ nanosheet. (c) $\mathrm{XRD}$ pattern of $\mathrm{TiO}_{2}$ nanosheets. HRTEM images of the side face (d) and top face (e) of $\mathrm{TiO}_{2}$ nanosheets. (f) Schematic illustration of the $\{001\}$ and $\{101\}$ "surface heterojunction".

(a)

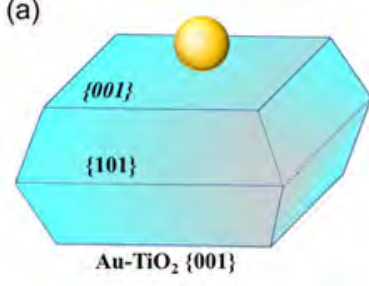

(d)

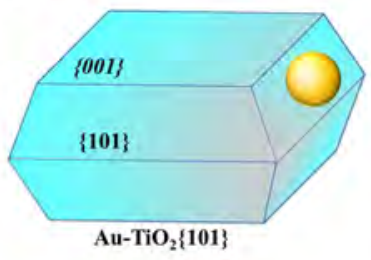

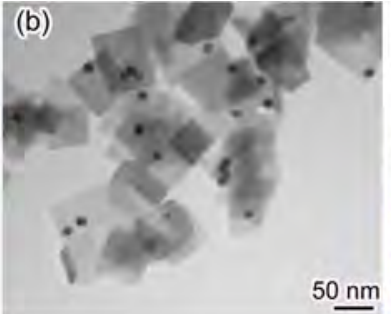

(e)

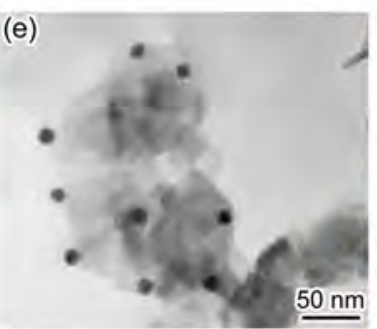

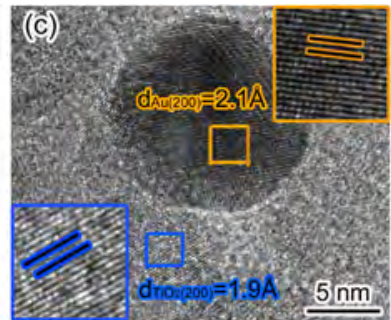

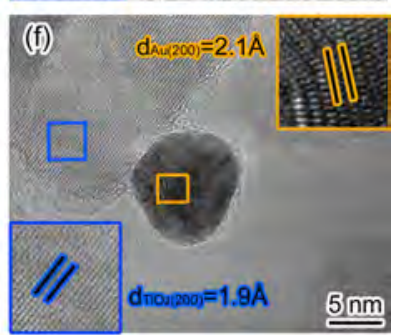

Fig. 2. Schematics of $\mathrm{Au}-\mathrm{TiO}_{2}\{001\}$ (a) and $\mathrm{Au}-\mathrm{TiO}_{2}\{101\}$ (d) hybrid structures. TEM images of $\mathrm{Au}-\mathrm{TiO}_{2}\{001\}$ (b) and $\mathrm{Au}-\mathrm{TiO}_{2}\{101\}$ (e) hybrid structures. HRTEM images of $\mathrm{Au}-\mathrm{TiO}_{2}\{001\}$ (c) and $\mathrm{Au}-\mathrm{TiO}_{2}\{101\}$ (f) hybrid structures.

was selected as an intermediate ligand because its thiol and carboxylic terminal groups can interact with $\mathrm{Au}$ NPs and $\mathrm{TiO}_{2}$ NSs, respectively [34]. MPA strongly bound to the NPs and NSs to efficiently load the Au NPs onto the $\mathrm{TiO}_{2} \mathrm{NSs}$. MPA was then removed by annealing at $200{ }^{\circ} \mathrm{C}$ to enhance the interfacial contact between the NPs and NSs. The TEM images in Fig. 2(b) and (c) clearly show that Au NPs are predominantly and uniformly distributed on the $\{001\}$ facets of $\mathrm{TiO}_{2} \mathrm{NSs}$, which is attributed to the dominant (001) surface coverage and small thickness of the $\mathrm{TiO}_{2} \mathrm{NSs}$. In the synthesis of $\mathrm{Au}-\mathrm{TiO}_{2}\{101\}$ through photoreduction (Fig. 2(d)), the photogenerated electrons on the \{101\} facets of $\mathrm{TiO}_{2}$ NSs, which were transferred from the $\{001\}$ facets, can reduce $\mathrm{Au}^{3+}$ to $\mathrm{Au}$ NPs to achieve the selective deposition of Au NPs on $\{101\}$ facets (Fig. 2(e)). HRTEM (Fig. 2(f)) revealed that the $\mathrm{Au}$ NPs and $\mathrm{TiO}_{2}$ NSs were in intimate contact, indicating the strong interaction between $\mathrm{Au}$ and $\mathrm{TiO}_{2}$ during the photoreduction process.

In the XRD patterns of the $\mathrm{Au}-\mathrm{TiO}_{2}\{001\}$ and $\mathrm{Au}-\mathrm{TiO}_{2}\{101\}$ hybrid structures in Fig. 3(a), the diffraction peak of Au NPs is overlapped by that of $\mathrm{TiO}_{2} \mathrm{NSs}$ at $38^{\circ}$. However, the peak at $44.3^{\circ}$ can be assigned to Au NPs, indicating the existence of $\mathrm{Au}$ NPs in the $\mathrm{Au}-\mathrm{TiO}_{2}$ hybrid structures. Compared with that of the $\mathrm{TiO}_{2} \mathrm{NSs}$, the UV-vis-NIR diffuse reflectance spectra of the $\mathrm{Au}-\mathrm{TiO}_{2}$ hybrid structures (Fig. 3(b)) show that the addition of $\mathrm{Au}$ NPs can broaden the absorption spectral range to the visible and even near-infrared regions. The peak at $550 \mathrm{~nm}$ is ascribed to the plasmonic absorption band of Au NPs. As a result, the hybrid structures could achieve light absorption over a broad wavelength range.

To reveal the plasmonic effect of the Au NPs on the $\mathrm{TiO}_{2} \mathrm{NSs}$, 

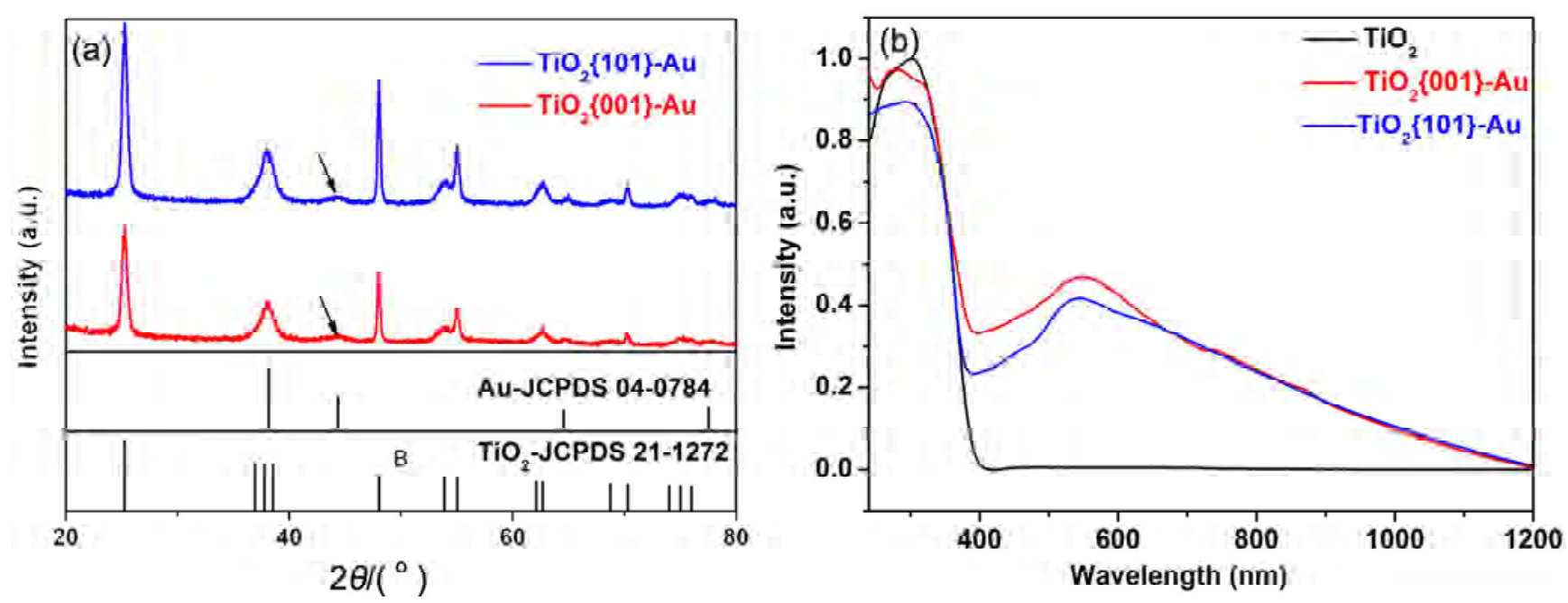

Fig. 3. (a) XRD patterns of $\mathrm{Au}-\mathrm{TiO}_{2}\{001\}$ and $\mathrm{Au}-\mathrm{TiO}_{2}\{101\}$ hybrid structures. (b) UV-vis-NIR diffuse reflectance spectra of $\mathrm{TiO}_{2} \mathrm{NSs}$ and $\mathrm{Au}-\mathrm{TiO}_{2}$ hybrid structures.

photocurrent measurements and photocatalytic hydrogen evolution of $\mathrm{TiO}_{2}$ and $\mathrm{Au}-\mathrm{TiO}_{2}$ samples were performed under visible-light irradiation. Because $\mathrm{TiO}_{2}$ NSs cannot be excited by visible light, this measurement setup prevented the interference of photogenerated electrons from $\mathrm{TiO}_{2}$ NSs. Fig. 4(a) displays the obvious photocurrent observed for $\mathrm{Au}-\mathrm{TiO}_{2}\{001\}$ and weak photocurrent from bare $\mathrm{TiO}_{2}$ NSs. This phenomenon can be attributed to the injection of plasmonic hot electrons from $\mathrm{Au}$ NPs into $\mathrm{TiO}_{2}$ NSs. Compared with $\mathrm{Au}-\mathrm{TiO}_{2}\{101\}$, the $\mathrm{Au}-\mathrm{TiO}_{2}\{001\}$ hybrid structure shows dramatically higher photocurrent densities. This indicates that the plasmonic hot electrons can be more efficiently injected into $\mathrm{TiO}_{2} \mathrm{NSs}$ through their $\{001\}$ facets than through their $\{101\}$ facets. To evaluate the photocatalytic activity of the $\mathrm{Au}-\mathrm{TiO}_{2}$ materials, their photocatalytic hydrogen evolution from water was selected as a model reaction (Fig. 4(b)), because it can exactly reflect the behavior of electrons in the photocatalytic process. No hydrogen evolution was observed for the bare $\mathrm{TiO}_{2} \mathrm{NSs}$ under visible-light illumination because $\mathrm{TiO}_{2}$ only absorbs UV light. Likewise, no hydrogen production was detected for the $\mathrm{Au}-\mathrm{TiO}_{2}\{101\}$ hybrid structure. Most likely, this results from the lack of a driving force to steer the migration of injected electrons towards the surface of $\mathrm{TiO}_{2}$ NSs for reduction reactions. In contrast, the $\mathrm{Au}-\mathrm{TiO}_{2}\{001\}$ hybrid structure exhibits apparent photocatalytic activity. This suggests that the interface between $\mathrm{Au}$ and $\mathrm{TiO}_{2}\{001\}$ facets indeed favors the injection of plasmonic hot electrons to facilitate reduction reactions.

The next question is how the $\{001\}$ and $\{101\}$ facets of $\mathrm{TiO}_{2}$ NSs affect the behavior of injected hot electrons from plasmonic $\mathrm{Au}$ NPs to the $\mathrm{TiO}_{2}$ NT surface. Because the work function of Au NPs $(\sim 5.1 \mathrm{eV})$ [32] is higher than that of $\mathrm{TiO}_{2}$ NSs $(\sim 4.9 \mathrm{eV})$ [38], a Schottky junction can form at the interface between $\mathrm{Au}$ NPs and $\mathrm{TiO}_{2}$ NSs. Under visible light, the plasmonic hot electrons photogenerated at Au NPs are injected into the $\mathrm{CB}$ of $\mathrm{TiO}_{2}$ NSs across the Schottky junction, while the holes are left on the $\mathrm{Au}$ NPs. If the injected electrons cannot be transported away quickly enough, the electrons accumulated in $\mathrm{TiO}_{2}$ will flow back to the Au NPs through the Schottky junction and recombine with the holes left in $\mathrm{Au}$, lowering the activity of reduction reactions. It is thus believed that the major reason for the limited photoactivity of $\mathrm{Au}-\mathrm{TiO}_{2}\{101\}$ is the lack of a driving force to steer the migration of the injected electrons and prevent the electrons from flowing back to recombine with holes. A "surface heterojunction" can play an important role in driving the migration of the injected electrons from the $\{001\}$ to $\{101\}$ facets of $\mathrm{TiO}_{2}$ NSs. As illustrated in Fig. 4(c), the plasmonic hot electrons injected through the $\{001\}$ facet can sequentially migrate towards the $\{101\}$ facet and separate from the holes via the "surface heterojunction", resulting in the higher photocatalytic activity of $\mathrm{Au}-\mathrm{TiO}_{2}\{001\}$ hybrid structure than that of the $\mathrm{Au}-\mathrm{TiO}_{2}\{101\}$ one. In sharp contrast, the $\mathrm{Au}-\mathrm{TiO}_{2}\{101\}$ interface does not offer the facet-dependent driving force for charge transfer, and as a result, the electrons injected through the $\{101\}$ facet may flow back to the Au NPs through the Schottky junction (Fig. 4(d)) [38].

To better resolve the facet-dependent charge transfer behavior of the structures, the facet-selective photodeposition of Pt NPs was carried out under visible-light irradiation. With the photogenerated electrons from the $\mathrm{Au}-\mathrm{TiO}_{2}$ hybrid structures, free $\mathrm{Pt}^{4+}$ in solution can be reduced to $\mathrm{Pt}^{0} \mathrm{NPs}$ and deposited on the hybrid structures. During this process, the migration behavior of photogenerated electrons can be determined. As shown in Fig. 4(e), Pt NPs can be clearly observed on the $\mathrm{TiO}_{2}$ NSs in the Au- $\mathrm{TiO}_{2}\{001\}$ hybrid structure, in good agreement with the proposed mechanism in Fig. 4(c). It is worth noting that the plasmonic hot electrons generated under visible-light irradiation are unlikely to migrate over a long distance to reach the $\{101\}$ facet in the absence of a co-catalyst given their short lifetime. For this reason, most Pt NPs are deposited on the $\{001\}$ facets near Au NPs, as shown in Fig. 4(e). Nevertheless, the driving force provided by the "surface heterojunction" can prevent the hot electrons from flowing back to recombine with 

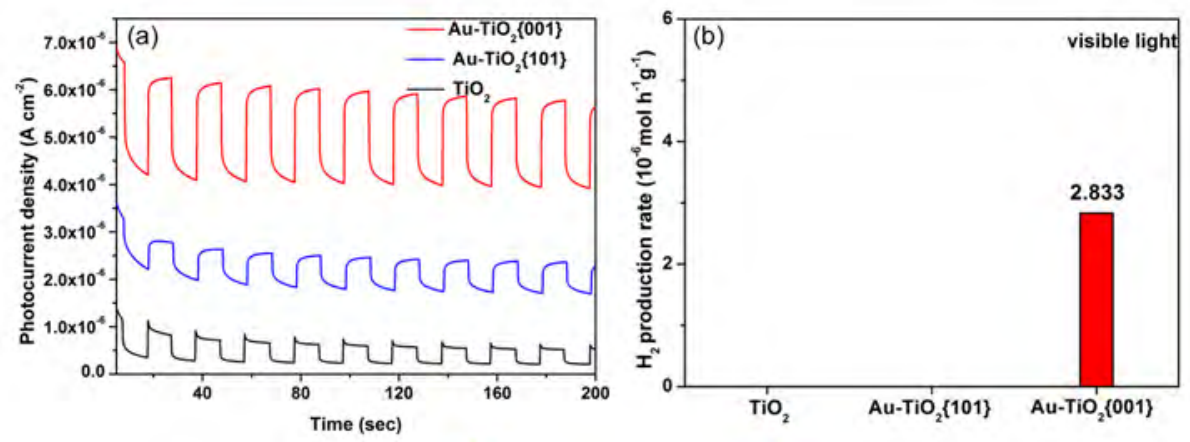

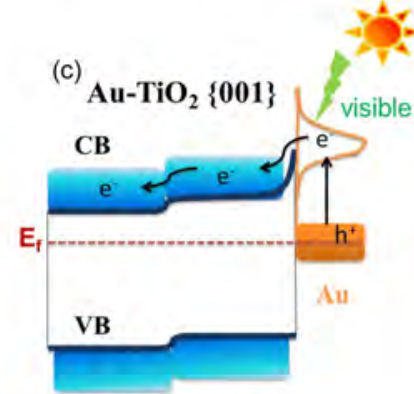

$\{101\}$ facet $\{001\}$ facet

$\mathrm{TiO}_{2}$

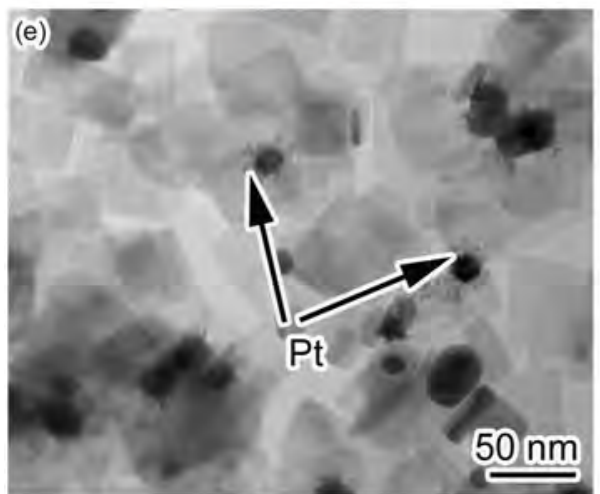

(d)

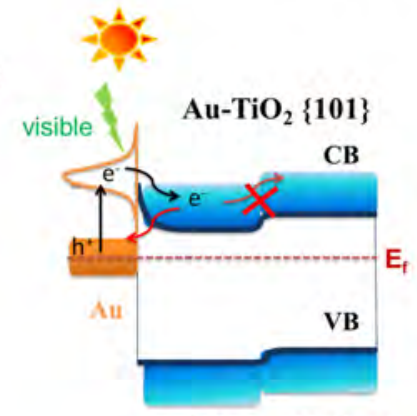

$\{101\}$ facet $\{001\}$ facet

$\mathrm{TiO}_{2}$

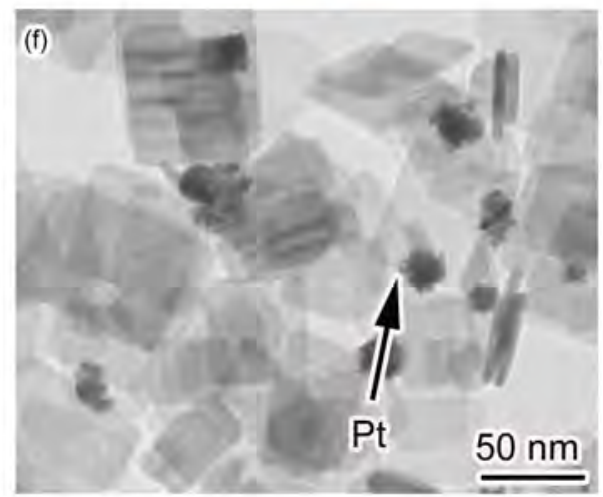

Fig. 4. (a) Photocurrent versus time (I-t) curves of $\mathrm{TiO}_{2} \mathrm{NSs}$ and $\mathrm{Au}-\mathrm{TiO}_{2}$ hybrid structures measured in $\mathrm{Na}_{2} \mathrm{SO}_{4}$ solution $(0.5$ mol/L) under visible-light irradiation $(\lambda>400 \mathrm{~nm})$. (b) Average rates for photocatalytic hydrogen evolution using $\mathrm{Au}_{-}-\mathrm{TiO}_{2}\{001\}$ and $\mathrm{Au}-\mathrm{TiO}{ }_{2}\{101\}$ as catalysts under visible-light irradiation. Schematics of the injection of hot electrons in $\mathrm{Au}-\mathrm{TiO}_{2}\{001\}$ (c) and $\mathrm{Au}-\mathrm{TiO}_{2}\{101\}$ (d). TEM images of $\mathrm{Au}-\mathrm{TiO}{ }_{2}\{001\}$ (e) and $\mathrm{Au}-\mathrm{TiO}_{2}\{101\}$ (f) with deposited Pt NPs.

holes. In contrast, the photodeposition of Pt NPs on the $\mathrm{Au}-\mathrm{TiO}_{2}\{101\}$ hybrid structure merely takes place near the $\mathrm{Au}$ NPs (Fig. 4(f)) because of the backflow of electrons to Au NPs. The facet-selective photodeposition observed here confirms that the integration of $\mathrm{Au}$ NPs with the $\{001\}$ facet of $\mathrm{TiO}_{2} \mathrm{NSs}$ is an effective approach to separate the injected electrons from holes and steer the migration of injected electrons towards the $\mathrm{TiO}_{2}$ NT surface. For this reason, the $\mathrm{Au}-\mathrm{TiO}_{2}\{001\}$ hybrid structure was selected for further research.

To further explore the possibility of using the hybrid structure to realize full-spectrum photocatalysis, photocatalytic hydrogen evolution over $\mathrm{Au}-\mathrm{TiO}_{2}\{001\}$ was performed under full-spectrum irradiation, during which $\mathrm{TiO}_{2}$ NSs and $\mathrm{Au}$ NPs were simultaneously excited to produce photogenerated electrons. As shown in Fig. 5(a), the hydrogen production rate by $\mathrm{Au}-\mathrm{TiO}_{2}\{001\}$ is slightly lower than that of the bare $\mathrm{TiO}_{2} \mathrm{NSs}$ at the same weight of $\mathrm{TiO}_{2}$. This performance degradation is essentially caused by the competition between the injection of plasmonic hot electrons and the Schottky junction-driven electron transfer. In comparison, $\mathrm{Au}-\mathrm{TiO}_{2}\{001\}$ shows higher photocatalytic activity than that of the bare $\mathrm{TiO}_{2}$ NSs under UV irradiation. This behavior reflects the ability of the Schottky junction to suppress charge recombination when only $\mathrm{TiO}_{2}$ is photoexcited. As illustrated in Fig. 5(b), the $\mathrm{TiO}_{2} \mathrm{NSs}$ and $\mathrm{Au}$ NPs in $\mathrm{Au}-\mathrm{TiO}_{2}\{001\}$ are simultaneously excited to produce photogenerated electrons and plasmonic hot electrons under full-spectrum irradiation, respectively. In this case, the injection of plasmonic hot electrons from $\mathrm{Au}$ NPs to $\mathrm{TiO}_{2} \mathrm{NSs}$ would be counteracted by the transfer of photogenerated electrons from $\mathrm{TiO}_{2}$ NSs to Au NPs through the Schottky junction, thereby resulting in a fairly low efficiency of photocatalytic hydrogen evolution. 

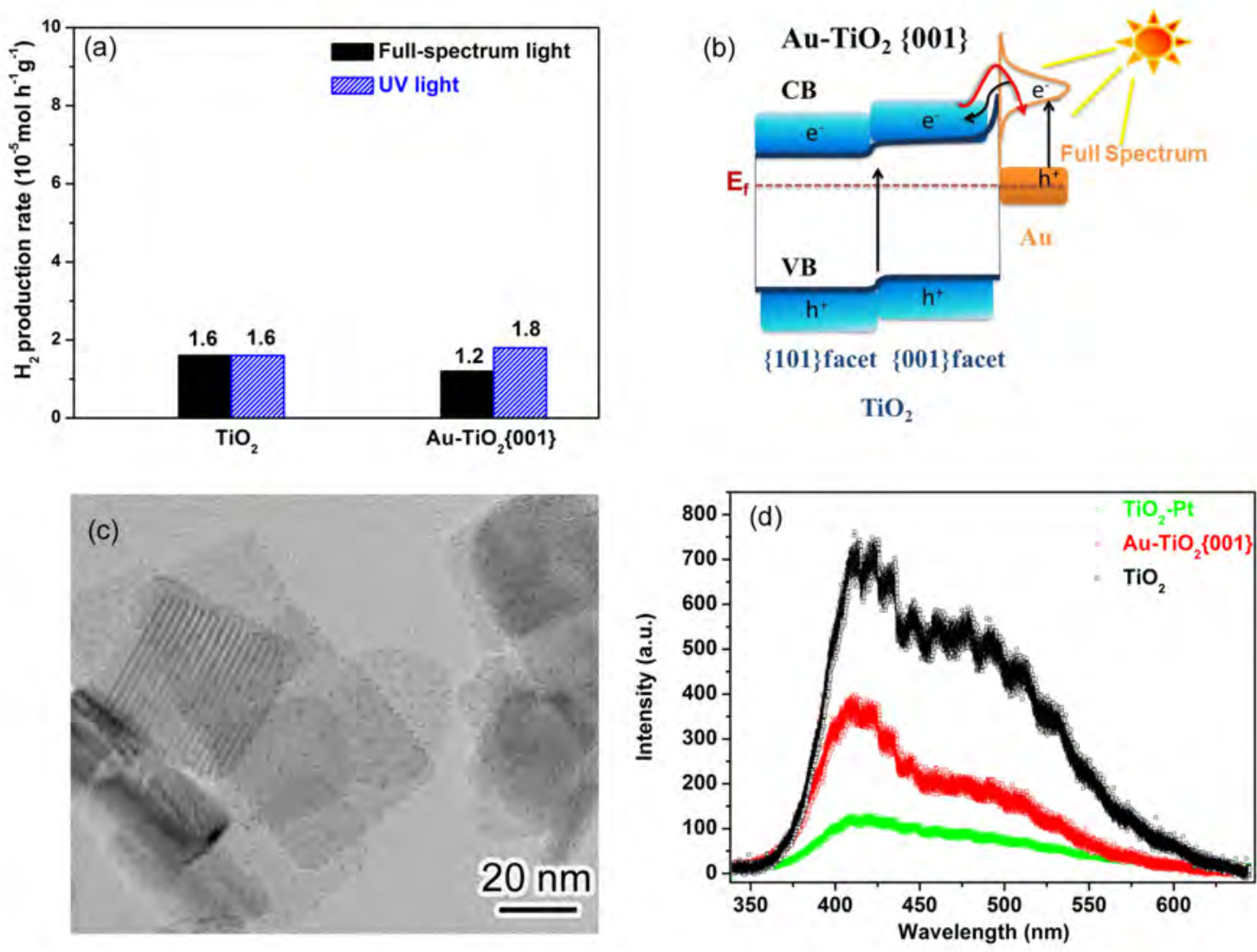

Fig. 5. (a) Average rates of photocatalytic hydrogen evolution using $\mathrm{TiO}_{2}$ and $\mathrm{Au}-\mathrm{TiO}_{2}\{001\}$ as catalysts under full-spectrum and UV irradiation. (b) Schematic of the migration of charge carriers in the $\mathrm{Au}-\mathrm{TiO}_{2}\{001\}$ hybrid structure under full-spectrum irradiation. (c) TEM image of TiO $2-\mathrm{Pt}$ hybrid structures. (d) Photoluminescence spectra of $\mathrm{TiO}_{2}, \mathrm{Au}-\mathrm{TiO}_{2}\{001\}$, and $\mathrm{TiO}_{2}-\mathrm{Pt}$.

To tackle the limitations of the $\mathrm{Au}-\mathrm{TiO}_{2}\{001\}$ hybrid structure and achieve full-spectrum photocatalysis, we introduced another metal as a co-catalyst to induce the flow of photogenerated electrons from $\mathrm{TiO}_{2}$ NSs to the co-catalyst and suppress their transfer back to Au NPs. Pt metal is generally used as a co-catalyst because it can establish a Schottky junction with a semiconductor. Such a co-catalyst can not only trap the electrons from $\mathrm{TiO}_{2}$, but also provide highly active sites for hydrogen evolution [39]. The uniform distribution of Pt $\mathrm{NPs}$ on $\mathrm{TiO}_{2}$ NSs was achieved through a chemical deposition method (Fig. 5(c)). PL spectroscopy (Fig. 5(d)) was used to examine the effect of the Pt co-catalyst on the separation and transfer of photoexcited charge carriers in the system because charge recombination generally induces luminescence. The PL spectrum of bare $\mathrm{TiO}_{2}$ NSs reveals the obvious recombination of photoexcited electrons and holes. The addition of metal NPs to $\mathrm{TiO}_{2} \mathrm{NSs}$ strongly quenched the PL, indicating the role of the Schottky junction in suppressing charge recombination. In particular, the introduction of Pt NPs caused substantially stronger PL quenching than was the case for Au NPs. This suggests that the photogenerated electrons from $\mathrm{TiO}_{2}$ NSs can be efficiently captured by Pt NPs to prevent their recombination with holes.

The information presented above has demonstrated the outstanding ability of Pt NPs as a co-catalyst to extract electrons from $\mathrm{TiO}_{2} \mathrm{NSs}$. We investigated the effect of Pt NPs in the
$\mathrm{Au}-\mathrm{TiO}_{2}\{001\}$ hybrid structure (namely, $\mathrm{Au}-\mathrm{TiO}_{2}\{001\}-\mathrm{Pt}$ ) on its photocatalytic hydrogen evolution under full-spectrum irradiation. The TEM image in Fig. 6(a) shows that the Pt NPs are well dispersed on $\mathrm{Au}-\mathrm{TiO}_{2}\{001\}$ following their photodeposition. In addition, XPS analysis of the $\mathrm{Au}-\mathrm{TiO}_{2}\{001\}-\mathrm{Pt}$ hybrid structure revealed Pt $4 f_{5 / 2}$ and $4 f_{7 / 2}$ peaks at 74.4 and $71.0 \mathrm{eV}$, respectively (Fig. 6(b)), indicating the formation of Pt NPs [40]. The Pt NPs supported on $\mathrm{TiO}_{2}$ NSs served as co-catalysts to promote charge separation, as manifested in photocatalytic hydrogen evolution. Compared with that of bare $\mathrm{TiO}_{2} \mathrm{NSs}$, $\mathrm{TiO}_{2}-\mathrm{Pt}$ exhibited an increased hydrogen production rate under full-spectrum irradiation, demonstrating the ability of the $\mathrm{Pt}$ co-catalyst to capture electrons from $\mathrm{TiO}_{2}$ NSs. Similarly, when $\mathrm{Au}-\mathrm{TiO}_{2}\{001\}$ was coated with Pt NPs, the hydrogen evolution rate reached about 155 and 206 times those of bare $\mathrm{TiO}_{2}$ NSs and $\mathrm{Au}-\mathrm{TiO}_{2}\{001\}$, respectively (Fig. 6(c)). In the $\mathrm{Au}-\mathrm{TiO}_{2}\{001\}-\mathrm{Pt}$ hybrid structure (Fig. 6(d)), the hot electrons injected from $\mathrm{Au}$ NPs to $\mathrm{TiO}_{2} \mathrm{NSs}$ can be steered by the "surface heterojunction" inside the $\mathrm{TiO}_{2} \mathrm{NSs}$, and be captured by Pt NPs for hydrogen evolution upon reaching $\mathrm{TiO}_{2}\{101\}$ facets. Meanwhile, the electrons excited from $\mathrm{TiO}_{2}$ NSs can also be captured by Pt NPs instead of flowing to Au NPs. As a result, the $\mathrm{Au}-\mathrm{TiO}_{2}\{001\}-\mathrm{Pt}$ hybrid structure displays dramatically enhanced performance in full-spectrum photocatalytic hydrogen evolution compared with that of bare $\mathrm{TiO}_{2} \mathrm{NSs}$. 

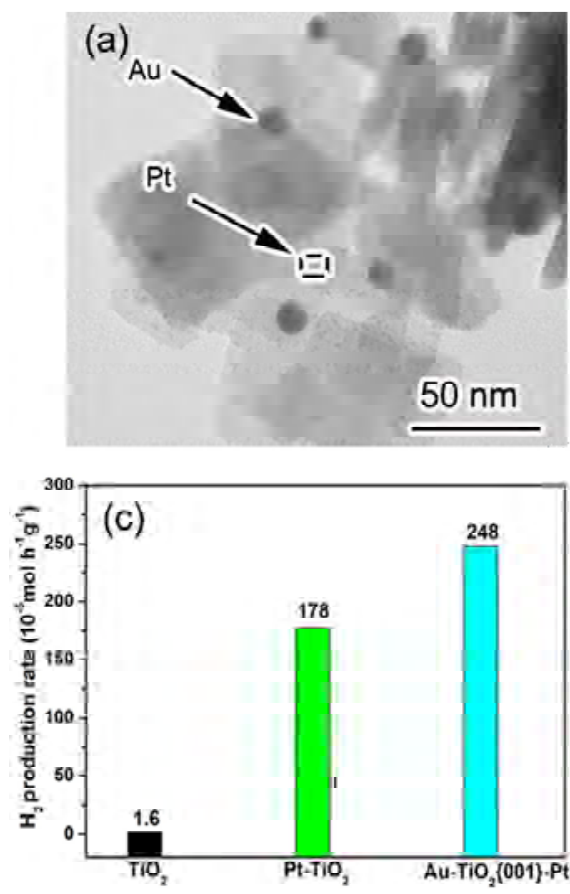

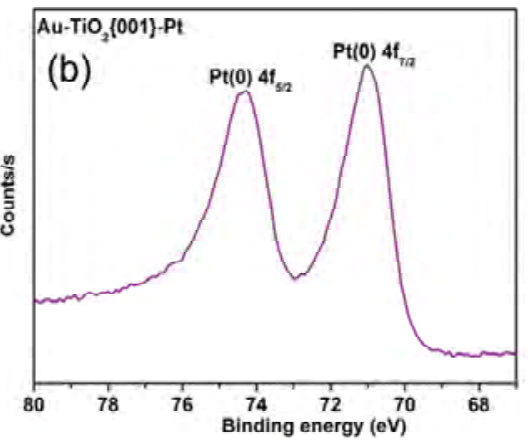

(d)

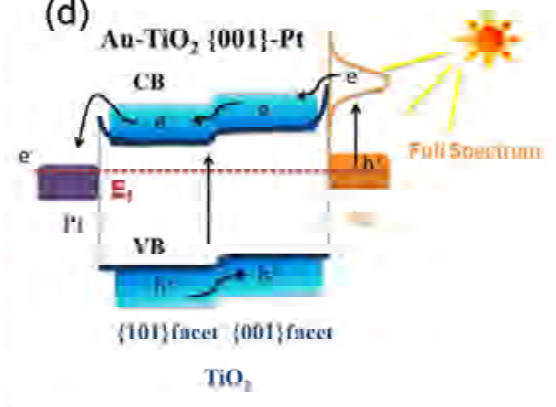

Fig. 6. (a) TEM image of the $\mathrm{Au}-\mathrm{TiO}_{2}\{001\}$-Pt hybrid structure. (b) Pt 4 XPS spectrum of the Au-TiO ${ }_{2}\{001\}-\mathrm{Pt}$ hybrid structure. (c) Average rates of photocatalytic hydrogen evolution with $\mathrm{TiO}_{2}, \mathrm{TiO}_{2}-\mathrm{Pt}$, and $\mathrm{Au}-\mathrm{TiO}_{2}\{001\}-\mathrm{Pt}$ hybrid structures as catalysts under full-spectrum irradiation. (d) Schematic of the migration of charge carriers in the $\mathrm{Au}-\mathrm{TiO}_{2}\{001\}$-Pt hybrid structure under full-spectrum irradiation.

\section{Conclusions}

In summary, we designed a hybrid catalyst structure to realize enhanced full-spectrum photocatalytic hydrogen evolution. This structure allows the photogenerated electrons from $\mathrm{TiO}_{2}$ NSs and plasmonic hot electrons from Au NPs to simultaneously contribute to photocatalysis by steering their migration by synergizing the "surface heterojunction" with the Schottky junction. In this design, the efficient injection of plasmonic hot electrons from Au NPs is achieved by integration with the $\{001\}$ facets of $\mathrm{TiO}_{2} \mathrm{NSs}$ under the driving force of the "surface heterojunction". Meanwhile, the photogenerated electrons from $\mathrm{TiO}_{2}$ NSs together with the injected hot electrons from Au NPs are captured by the Pt NPs present as a co-catalyst to induce hydrogen evolution. As a result, this hybrid structure showed dramatically enhanced performance in photocatalytic hydrogen production under full-spectrum irradiation compared with that of $\mathrm{TiO}_{2}$ NSs. This work opens a new window for the rational design and synthesis of efficient hybrid structures to achieve plasmon-enhanced full-spectrum photocatalysis.

\section{References}

[1] X. Chen, S. S. Mao, Chem. Rev., 2007,107, 2891-2959.

[2] G. Liu, L. Z. Wang, H. G. Yang, H. M. Cheng, G. Q. Lu, J. Mater. Chem., 2010, 20, 831-843.

[3] O. K. Varghese, M. Paulose , C. A. Grimes, Nat. Nanotechnol., 2009, 4, 592-597.

[4] X. L. Hu, G. S. Li, J. C. Yu, Langmuir, 2010, 26, 3031-3039.
[5] S. P. Albu, A. Ghicov, J. M. Macak, R. Hahn, P. Schmuki, Nano Lett., 2007, 7, 1286-1289.

[6] A. Kudo, Y. Miseki, Chem. Soc. Rev., 2009, 38, 253-278.

[7] M. Zeng, Y. Z. Li, M. Y. Mao, J. L. Bai, L. Ren, X. J. Zhao, ACS Catal., 2015, 5, 3278-3286.

[8] Z. J. Ning, H. N. Tian, C. Z. Yuan, Y. Fu, H. Y. Qin, L. C. Sun, H. Agren, Chem. Commun., 2011, 47, 1536-1538.

[9] A. Kongkanand, K. Tvrdy, K. Takechi, M. Kuno, P. V. Kamat, J. Am. Chem. Soc., 2008, 130, 4007-4015.

[10] Y. B. Chen, L. J. Guo, J. Mater. Chem., 2012, 22, 7507-7514.

[11] S. X. Min, G. X. Lu, J. Phys. Chem. C, 2011, 115, 13938-13945.

[12] R. Shi, Y. H. Cao, Y. J. Bao, Y. F. Zhao, G. I. N. Waterhouse, Z. Y. Fang, L. Z. Wu, C. H . Tung, Y. D. Yin, T. R. Zhang, Adv. Mater., 2017, 29, 1700803.

[13] K. Wu, J. Chen, J. R. McBride, T. Lian, Science, 2015, 349, 632-635.

[14] S. Linic, U. Aslam, C. Boerigter, M. Morabito, Nat. Mater., 2015, 14, 567-576.

[15] C. Zhou, L. Shang, H. J. Yu, T. Bian, L. Z. Wu, C. H. Tung, T. R. Zhang, Catal. Today, 2014, 225, 158-163.

[16] J. M. Liu, L. Han, H. Y. Ma, H. Tian, J. C. Yang, Q. C. Zhang, B. J. Seligman, S. B. Wang, J. Liu, Sci. Bull., 2016, 61,1543-1550.

[17] X. N. Wang, R. Long, D. Liu, D. Yang, C. M. Wang, Y. J. Xiong, Nano Energy, 2016, 24,87-93.

[18] W. Y. Jiang, S. Bai , L. M. Wang, X. J. Wang, L. Yang, Y. R. Li , D. Liu , X. N. Wang, Z. Q. Li , J. Jiang , Y. J. Xiong, Small, 2016, 12, 1640-1648.

[19] S. J. Tan, L. M. Liu, Y. N. Dai, J. D. Ren, J. Zhao, H. Petek, J. Am. Chem. Soc., 2017, 139, 6160-6168.

[20] X. F. Zhou, C. Hu, X. X. Hu, T. W. Peng, J. H. Qu, J. Phys. Chem. C, 2010, 114, 2746-2750.

[21] S. F. Hung, F. X. Xiao, Y. Y. Hsu, N. T. Suen, H. B. Yang, H. M. Chen, B. Liu, Adv. Energy Mater., 2016, 6, 1501339. 


\section{Graphical Abstract}

Chin. J. Catal., 2018, 39: 453-462 doi: 10.1016/S1872-2067(17)62938-3

\section{Steering plasmonic hot electrons to realize enhanced full-spectrum photocatalytic hydrogen evolution}

Yanrui Li, Yu Guo, Ran Long, Dong Liu, Daming Zhao, Yubo Tan, Chao Gao*, Shaohua Shen*,Yujie Xiong*

Xi'an Jiaotong University; University of Science and Technology of China

An efficient strategy is developed to steer the migration of plasmonic hot electrons using a well-designed hybrid structure that synergizes a "surface heterojunction" with a Schottky junction to achieve highly efficient full-spectrum photocatalytic hydrogen production.

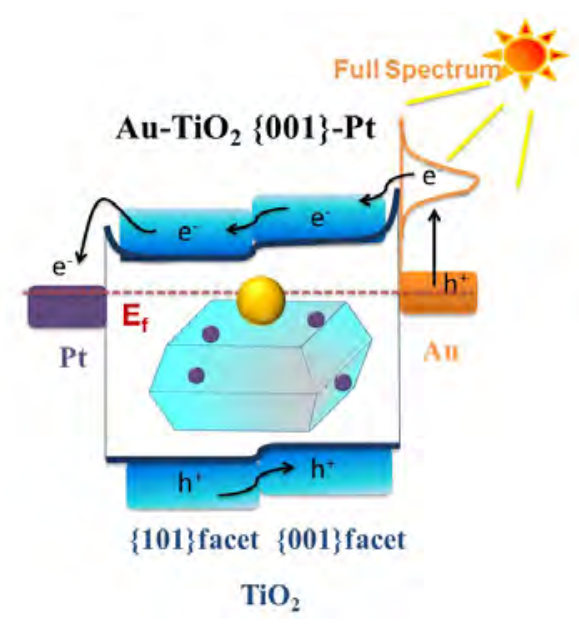

Whangbo, Angew. Chem. Int. Ed., 2008, 47, 7931-7933.

[22] S. Bai, J. Jiang, Q. Zhang, Y. J. Xiong, Chem. Soc. Rev., 2015, 44, 2893-2939.

[23] H. Yoo, C. Bae, Y. Yang, S. Lee, M. Kim, H. Kim, Y. Kim, H. Shin, Nano Lett., 2014, 14, 4413-4417.

[24] A. Tanaka, K. Nakanishi, R. Hamada, K. Hashimoto, H. Kominami, ACS Catal., 2013, 3, 1886-1891.

[25] H. X. Li, Z. D. Li, Y. H. Yu, Y. J. Ma, W. G. Yang, F. Wang, X. Yin, X. D. Wang, J. Phys. Chem. C, 2017, 121, 12071-12079.

[26] S. W. Liu, J. G. Yu, M. Jaroniec, Chem. Mater., 2011, 23, 4085-4093.

[27] J. G. Yu, J. X. Low, W. Xiao, P. Zhou, M. Jaroniec, J. Am. Chem. Soc., 2014, 136, 8839-8842.

[28] L. L. Wang, J. Ge, A. L. Wang, M. S. Deng, X. J. Wang, S. Bai, R. Li, J. Jiang, Q. Zhang, Y. Luo ,Y. J. Xiong, Angew. Chem. Int. Ed., 2014, 53, 5107-5111.

[29] X. H. Li, M. Antonietti, Chem. Soc. Rev., 2013, 42, 6593-6604.

[30] H. L. Wang, L. S. Zhang, Z. G. Chen, J. Q. Hu, S. J. Li, Z. H. Wang, J. S. Liu, X. C. Wang, Chem. Soc. Rev., 2014, 43, 5234-5244.

[31] P. Wang, B. B. Huang, X. Y. Qin, X. Y. Zhang, Y. Dai, J. Y. Wei, M. H.
[32] P. Yu, X. M. Wen, Y. C. Lee, W. C. Lee, C. C. Kang, J. Tang, J. Phys. Chem. Lett., 2013, 4, 3596-3601.

[33] X. G. Han, Q. Kuang, M. S. Jin, Z. X. Xie, L. S. Zheng, J. Am. Chem. Soc., 2009, 131, 3152-3153.

[34] D. W. Ding, K. Liu, S. N. He, C. B. Gao, Y. D. Yin, Nano Lett., 2014, 14, 6731-6736.

[35] W. Li, Z. X. Wu, J. X. Wang, A. A. Elzatahry, D. Y. Zhao, Chem. Mater., 2014, 26, 287-298.

[36] Z. K. Zheng, B. B. Huang, J. B. Lu, X. Y. Qin, X.Y. Zhang, Y. Dai, Chem. Eur. J., 2011, 17, 15032-15038.

[37] J. Schneider, M. Matsuoka, M. Takeuchi, J. L. Zhang, Y. Horiuchi, M. Anpo, D. W. Bahnemann, Chem. Rev., 2014, 114, 9919-9986.

[38] R. T. Tung, Appl. Phys. Rev., 2014, 1, 011304.

[39] J. R. Ran, J. Zhang, J. G. Yu, M. Jaroniecc, S. Z. Qiao, Chem. Soc. Rev., 2014, 43, 7787-7812.

[40] H. L. Wang, Y. H. Wang, Z. W. Zhu, A. Sapi, K. An, G. Kennedy, W. D. Michalak, G. A. Somorjai, Nano Lett., 2013, 13, 2976-2979.

\section{基于等离激元热电子调控的全谱光催化产氢增强}

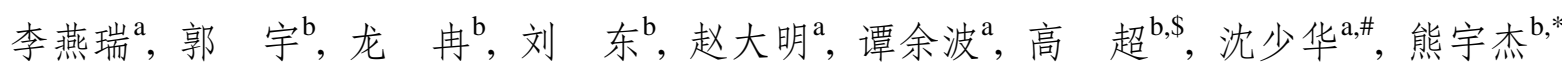

a西安交通大学, 动力工程多相流国家重点实验室, 国际可再生能源研究中心, 陕西西安710049

${ }^{\mathrm{b}}$ 中国科学技术大学, 化学与材料科学学院, 能源材料化学协同创新中心, 合肥微尺度物质科学国家实验室, 安徽合肥 230026

摘要: 等离激元效应在光催化体系中的集成为实现广谱光吸收提供了一个新的途径, 然而等离激元热电子的较低迁移率 和不确定扩散方向使得其光催化效率仍较低. 等离激元金属与n型半导体接触后, 其界面间会形成肖特基结. 在特定波长 太阳光照射下, 等离激元金属将其表面等离子体能量聚集在表面自由电子上, 进而产生热电子. 当这些热电子具有的能量 高于肖特基势垒时, 热电子便可注入到半导体导带上. 与此同时, 半导体上的电子可以通过肖特基接触发生回流, 与金属 上的空穴复合, 进而降低半导体-等离激元金属复合材料的光催化性能. 因此, 为了提高光催化效率, 如何调控等离激元热 电子迁移和充分利用等离激元效应是一个重要挑战.

本文尝试将 “表面异质结”与肖特基结相结合的复合结构, 得以有效地调控等离激元热电子的迁移. 在该复合结构中, 金纳米颗粒和铂纳米颗粒分别作为等离激元吸光单元和助催化剂, 集成在 $\mathrm{TiO}_{2}$ 纳米片表面. 其中 “表面异质结” 是由 $\mathrm{TiO}_{2}$ 纳 米片的两种不同表面晶面所构成, 我们选择由 $\{001\}$ 和 $\{101\}$ 两组晶面组成的 $\mathrm{TiO}_{2}$ 纳米片作为半导体祄底. 该结构中的 $\{001\}$ 晶面导带能级高于 $\{101\}$ 导带能级, 因而电子由高能级的 $\{001\}$ 流向低能级的 $\{101\}$ 晶面, 可以用来引导等离激元热电 子从可见光响应的金纳米颗粒向 $\mathrm{TiO}_{2}$ 进行高效转移. 通过巯基丙酸的桥联作用, 将等离激元 $\mathrm{Au}$ 纳米颗粒针定在 $\mathrm{TiO}_{2}$ 纳米 
片的 $\{001\}$ 晶面上, 获得 $\mathrm{Au}-\mathrm{TiO}_{2}\{001\}$ 样品. 另一方面, 利用 $\mathrm{TiO}_{2}$ 纳米片自身光生电荷导向性光沉积, 得到与 $\{101\}$ 晶面结合 形成的 $\mathrm{Au}-\mathrm{TiO}_{2}\{101\}$ 样品. 我们对两组样品进行光电流和光催化产氢实验对比, 确认在 “表面异质结”诱导下Au- $\mathrm{TiO}_{2}\{001\}$ 样品中 $\mathrm{Au}$ 产生的光生热电子可以更好地注入到 $\mathrm{TiO}_{2}$ 纳米片导带上. 我们进一步通过光沉积 $\mathrm{Pt}$ 纳米颗粒来判定光生电子所 能到达的区域, 验证了以上结论. 与此同时, 肖特基结由铂纳米颗粒与 $\mathrm{TiO}_{2}$ 纳米片所形成, 可以促使电子由 $\mathrm{TiO}_{2}$ 向铂纳米颗 粒进行转移, 而避免发生向金纳米颗粒的反向迁移, 从而在 $\mathrm{Au}-\mathrm{TiO}_{2}$ 体系中实现高效的单向载流子转移. 基于该设计, 等离 激元光催化剂实现了明显改善的全谱光催化产氢性能. 本文为全谱光催化的复合结构理性设计提供了一个新的思路.

关键词: 等离激元; 表面异质结; 肖特基结; 光催化产氢; 全谱光照

收稿日期: 2017-09-26. 接受日期: 2017-10-21. 出版日期: 2018-03-05.

*通讯联系人. 电话/传真: (0551)63606657; 电子信箱: yjxiong@ustc.edu.cn

\#通讯联系人. 电话/传真: (029)82668296; 电子信箱: shshen_xjtu@mail.xjtu.edu.cn

\$通讯联系人. 电话/传真: (0551)63600651; 电子信箱: gaoc@ustc.edu.cn

基金来源：国家重点研发计划专项项目(2017YFA0207301); 国家重点基础研究发展计划(973计划, 批准号2014CB848900); 国家 自然科学基金(21471141, U1532135); 中国科学院前沿科学重点研究项目(QYZDB-SSW-SLH018); 中国科学院创新交叉团队, 合 肥物质科学技术中心方向项目(2016FXCX003); 国家千人计划; 中科院百人计划; 安徽省自然科学基金(1708085QB26); 中国博 士后科学基金(BH2060000034); 中央高校基本科研业务费专项资金(WK2060190064).

本文的英文电子版由Elsevier出版社在ScienceDirect上出版(http://www.sciencedirect.com/science/journal/18722067). 